\title{
Work Turnover and Its Impact on the Quality of Productivity in the Industrial Sector
}

\author{
Aisha Abdullah Mahjob Jamal \\ ${ }^{1}$ Department of Human Resources Management, Faculty of Business, University of Jeddah, Saudi Arabia \\ Correspondence: Aisha Abdullah Mahjob Jamal, Assistant Professor, Department of Human Resources Management, \\ Faculty of Business, University of Jeddah, Saudi Arabia.
}

Received: October 24, 2019

Accepted: November 15, 2019

Online Published: December 22, 2019

doi:10.5430/rwe.v10n4p65

URL: https://doi.org/10.5430/rwe.v10n4p65

\begin{abstract}
The aim of this study was to identify the effect of high turnover on quality of productivity in the industrial sector, and to propose appropriate solutions to reduce the reasons for leaving work. The motivation to carry out this study, the spread of the turnover phenomenon leading to dysfunction is in the interest of the organization, and has a direct impact on the decline in the quality of productivity of the organization, so was applied to the industrial sector to know and measure this impact. The methodology used in this study is the descriptive and analytical approach and the case study methodology.

The results of the study show that there is a relationship of statistical significance between the average level of performance of the employee and the level of total productivity in the organization. And that there is a middle relationship between job stability and employee performance level, and that there is a negative relationship between the turnover rate and quality of productivity in the industrial sector. The study recommends that employers try to retain existing workers and provide appropriate incentives for them to reduce the rate of turnover in institutions, because turnover is a cost to institutions that can be eliminated by retaining staff and institutions should improve financial and non-financial compensation in proportion to the circumstances And staff needs to ensure job stability and ensure quality of productivity.
\end{abstract}

Keywords: job rotation, job stability, quality of productivity

\section{Introduction}

Recently, researchers have become increasingly interested in the efficiency and quality of organizations' performance and their impact on the search for means to ensure that organizations excel in competition, especially in markets operating under a free economic system. From an economic perspective, the focus tends to reduce the cost of productivity. This is one of the indicators of the quality of productivity. Organizations of different kinds have a large direct and indirect cost due to some phenomena of human behavior of individuals in organizations. These phenomena lead to increased cost and reduced quality.

The turnover of work leads to the organization's loss of competencies and expertise that have been trained for long periods of time to reach the required quality of performance and thus the quality of the organization's productivity. The workers often move to competitive organizations that offer temptations that are better according to the needs of each individual. This is followed by a time lag in production until the appropriate individual is recruited and trained to the desired level of good performance that achieves productivity, with the time, effort, and cost (Alish, 1985) (Note 1).

Many researchers have noted that this phenomenon is a complex problem in the field of administrative research because of the lack of clarity of their real causes.

It should be noted that this problem exists in different types of organizations, and prevails among different individuals, administrative and professional levels without discrimination in sex or age, only with relative disparity depending on a number of factors and elements that converge leading to so-called job satisfaction, To a state of job stability, reflected in the meanings of belonging and loyalty to the organization, and commitment to quality of production and achievement of goals.

In view of the importance of this topic, this study is intended to shed light on the impact of labor turnover on the 
quality of productivity in the industrial sector.

\subsection{Problem Statement}

The problem of the study is that there is a phenomenon of replacement and replacement of some workers in organizations, which have an impact on the quality and efficiency of productivity in these organizations, and the question arises what are the most important factors that cause the turnover of work directly or indirectly? What is the impact of labor turnover on the productivity of the industrial sector? How can the effects of high turnover be addressed?

\subsection{Importance}

This study is one of the important studies in the fields of research and studies that shed light on one of the factors that affect the quality of productivity in general and in the industrial sector in particular, as the high turnover rate is the most important point of weakness in the quality of the performance of institutions It is threatened by the lack of accumulation of experience, knowledge and skills, therefore, the quality is low. Once the worker is employed and trained, he starts the real production until he leaves to another facility, depriving the first establishment of his experience and starting with the second establishment from scratch.

\subsection{Objectives of the Study}

1- Highlight the factors leading to job stability.

2 - To recognize the impact of high turnover on quality of productivity in the industrial sector.

3 - Propose solutions that may be appropriate to address the reasons that lead to leaving work and dispensing with it.

\subsection{Methodology of the Study}

The methodology used in this study is the descriptive and analytical approach and the case study methodology.

\subsection{Study Hypotheses}

1. There is a relationship between the factors leading to the stability of the job and the level of performance of the employee.

2 - There is a direct relationship between the level of performance of the employee work and the level of overall productivity in the organization.

3. There is a relationship between the turnover rate and the quality of productivity in the industrial sector.

\section{Previous Studies}

1 - Study (Al - Mutairi, 2012) entitled: The impact of turnover of employees on financial performance.

The objective of this study is to know the effect of the turnover of employees on the financial performance in the Kuwaiti Islamic banking sector. The researcher followed the analytical descriptive method. The study population consists of all Kuwaiti Islamic banks. The study sample consisted of all the administrators and accountants working in these banks. A sample of (100) employees was taken by 25 questionnaires for each bank. The financial statements of the banks under study were also used to prove the study. The turnover of employees in Kuwaiti Islamic banks was obtained through the records of these banks during the period 2006-2010. The SPSS program was used to analyze the data. The hypotheses were tested using the simple regression test and the 2Way ANOVA test. The following results were obtained: 1 - There is a statistically significant effect of the turnover of employees on the financial performance in the Kuwaiti Islamic banking sector. 2 - There are differences in the impact of the turnover of employees on the financial performance in the sector of Islamic banks in Kuwait attributed to the size of the bank (as measured by the number of employees). 3 - There are no differences in the impact of the turnover of employees on the financial performance in the sector of Islamic banks Kuwait attributed to the experience of the bank. Among the most important recommendations reached by the researcher:

1) focus on using the latest technological means to facilitate the work of the employee in a way that helps to improve his desire to work. 2) Provide a good incentive system at the bank to encourage the employee to continue to work efficiently. 3) Work on the implementation of a mechanism to control the performance of the employee linking performance with the incentives that he takes, and in a way that contributes to increase his desire to work. 4) Conducting studies on the subject by applying them to other economic sectors. (Note 2)

2 - Study (Abdel-Al, 2014) entitled: The impact of employee satisfaction on the turnover of employment.

The study aims to identify the importance of the stability of workers to the origin and identify the positive or 
negative factors affecting the process of turnover of labor, and try to avoid the high turnover of employment and thus the rise in productivity and the prosperity of institutions and progress and continuity. The researcher used the analytical descriptive method in the study, and the study was conducted on all employees of Al-Babtain Company for Energy and Communications, 559 workers through the distribution of a questionnaire, the correct answers were 282 individuals representing all categories of the study of technicians, engineers and administrators. The researcher also used many statistical methods suitable for the variables of the study through the statistical program SPSS, Also, the appropriate statistical tests were conducted for the study hypotheses,

1) that there is a strong correlation between the rate of turnover of labor and elements of employee satisfaction (satisfaction with wages and incentives, satisfaction with the management method, satisfaction with the development of employment) individually and collectively. 2) The level of satisfaction of the company's employees is average and the correlation of employee satisfaction is strong with the turnover rate. 3) There are other factors affecting the rate of turnover of labor, such as the general economic factor of the labor market, whether in a boom or recession. The study also reached a number of recommendations, the most important of which are:

1) The management of the company must continue to compete in wages, supply and demand in certain competencies so that the lack of proper supply does not lead to the migration of competencies to other places. 2) Work on the selection of leaders and supervisors in the company under study to have the ability and skill to encourage their subordinates to participate in the formulation of plans and objectives. 3) Focus on the groups and work teams and emphasize the dissemination of the culture of teamwork, which requires the adoption of the company to a full range of training and educational programs that aim to support the existing relationships human interaction and integration and to achieve better achievement, which distinguishes the good work environment and in turn to achieve career stability. (Note 3)

\section{The Theoretical Framework of the Study}

Definition of Work Cycle:

Is the phenomenon of change in the number of employees as a result of joining or leaving the job.

It is defined as: the movement of a voluntary worker outside the boundaries of the organization in which he works, whether by transport, resignation or early retirement.

Means the transfer: a process that changes the unit in which the employee works to another unit with the same salary.

The resignation means the written request submitted by the individual to the official body in his desire to leave the work.

Early retirement: It is like resignation, but it is not after a period of service after which deserves a full pension.

Method of Calculating Turnover: (Note 4)

Number of employees who left the service $=\mathrm{x} 100$ Number of employees who left their jobs

Average number of employees

The turnover rate (or rate of departure) is used as follows:

$1 /$ To predict the number of employees who will leave the service within the next year. Thus replacement needs can be identified. 2 / Recognize the extent of low satisfaction and morale and the high rate of leaving the service is an indicator of low satisfaction and morale.

3 / Know the level of quality of productivity in light of the continuous change in the competencies and experience of workers.

Work Cycle Types:

\section{Work turnover is divided into several types:}

\section{Voluntary turnover and involuntary turnover:}

The voluntary turnover is voluntary when the employee leaves his or her work, but if it is involuntary, it is voluntary. Voluntary reasons for leaving work include having a job with better pay or higher responsibilities, returning to full-time schooling, involuntary causes of death, chronic illness, the husband.

\section{2 - Turnover of work leading to dysfunction and turnover of work:}

The turnover of work leading to dysfunction is not in the interest of the organization, where turnover is considered to cause dysfunction when the difference resulting from turnover is negative to the labor force or positive but cannot 
offset the costs of turnover. While the Organization encourages the turnover of the job and the rotation of the job function if the employee's departure from the productivity of the organization increases, so that the resulting difference in the workforce is positive and sufficient to compensate for the turnover of work.

3 - Rotation of internal and external work:

Internal turnover occurs when the employee moves to another location within the organization to satisfy all parties, while external turnover occurs when a staff member separates from another organization.

Reasons for turnover: (Note 5)

1. The administration shall terminate the service either in the final dismissal or temporary dismissal.

2. Resigning from work due to difficult working conditions or finding a better job opportunity outside the organization.

3 - Referral to retirement when the legal age.

4. Demobilization or dismissal for errors committed by the staff member adversely affected the organization.

5. Death.

6. Disability.

\section{The costs of the work that lead to low productivity: (Note 6)}

Of the costs incurred by the institution due to high turnover: 1 . Cost of recruitment: It includes various costs resulting from the recruitment of new staff such as: advertising costs, tests and others. 2. Cost of training: It includes various costs directed at raising the skills of new employees in order to integrate them into their new jobs. 3 . Time-to-completion costs and quality of performance for new personnel when loss of experienced and efficient staff is performed.

\section{Factors affecting business turnover:}

The following are the most important factors affecting the process of turnover:

1. FAO support: The support of the organization is directly related to the career commitment, as well as the rotation process. The reason for the inability of staff to continue to carry out their functions effectively is their low commitment to the organization, low moral work, and a desire to leave work and seek other work.

2. Emotional stress: is a term used to describe people who suffer psychologically and morally. Employees who work directly with clients find that they are often prone to psychological stress and reduced job satisfaction. The inability to cope with psychological, mental and emotional exhaustion drives many of them to leave their jobs.

3. Job Satisfaction Job satisfaction is one of the most widely studied concepts in various sectors and organizations, and its relevance to many other institutional factors, such as organizational loyalty, organizational justice, turnover, and other factors.

4. Institutional justice: The issue of organizational justice is an important issue in the field of administration. Several studies have indicated that lack of objectivity and unfairness has many negative effects on staff and may be a cause of turnover.

5. Content of the job: content includes those aspects that determine the nature of the work, namely, diversity, independence, degree of complexity and monotony, degree of difficulty in addition to the methods in which the functions of the job.

6. Work conditions are not favorable: The framework includes material and moral variation. Material working conditions include factors such as temperature, ventilation, dust, and distance from the workplace. Work hazards arising from work on hazardous areas or work on rough terrain and harsh weather conditions.

7. Lack of leadership effectiveness: Leadership is the ability to influence the subordinates through active communication, to engage - with enthusiasm and commitment - to perform well, if the leader lacks the ability to influence subordinates, I said their desire to perform and showed a tendency to think about the voluntary leave of the job. (Note 7)

\section{The Applied Framework of the Study}

\subsection{Research Methodology}

This section deals with research methodology, community and sample of research as well as research tools used in 
addition to data collection procedures and methods of statistical analysis.

Methodology: The study was based on the descriptive and analytical approach and the case study methodology.

Research community: The research community consists of workers in Jeddah Plastic Factory, Saudi Arabia.

Sample: A random sample of (82) workers was selected in the Jeddah Plastic Factory.

Research Tools: After defining the objectives of the research, a questionnaire form consisting of 18 paragraphs was designed to include three axes. The first axis:

Factors leading to job stability (6) paragraphs, the second axis: the extent of the impact of the level of performance of the employee on the total productivity of the organization (6) paragraphs, the third axis, the extent of the impact of the turnover of work on the quality of productivity in the factory (6) paragraphs. In addition to (5) personal questions.

Reliability and stability of the study tool

Internal consistency: The validity of internal consistency was calculated by means of the Pearson correlation coefficient to determine the extent to which each paragraph was associated with the dimension to which it belongs. All of these were derived from the dimension to which they belong at the level of 0.01 . And the significance level of 0.05 as the table below.

Table 1. Pearson correlation coefficient between the paragraph and the dimension to which it belongs

Axis I: Factors leading to job The second axis: the extent of the impact The third axis: the extent of the stability of the turnover on the overall effect of labor turnover on the productivity of the organization productivity of the factory

\begin{tabular}{rrrrrrrrrrrr}
\hline $\mathrm{M}$ & $\mathrm{T}$ & $\mathrm{M}$ & $\mathrm{T}$ & $\mathrm{M}$ & $\mathrm{T}$ & $\mathrm{M}$ & $\mathrm{T}$ & $\mathrm{M}$ & $\mathrm{T}$ & $\mathrm{M}$ & $\mathrm{T}$ \\
\hline 1 & $0.307^{*}$ & 4 & $.736^{* *}$ & 1 & $.687^{* *}$ & 4 & $.273^{* *}$ & 1 & $.298^{*}$ & 4 & $.825^{* *}$ \\
\hline 2 & $.427^{*}$ & 5 & $.805^{* *}$ & 2 & $.781^{* *}$ & 5 & $.617^{* *}$ & 2 & $.785^{* *}$ & 5 & $.488^{*}$ \\
\hline 3 & $.555^{* *}$ & 6 & $.457^{*}$ & 3 & $.611^{* *}$ & 6 & $.659^{* *}$ & 3 & $.745^{* *}$ & 6 & $.505^{*}$ \\
\hline
\end{tabular}

Source: Field study procedures 2018.

** D statistic at the significance level of $0.01, * \mathrm{D}$ statistically at the significance level of 0.05 .

Formal truth: Formal truth was calculated by measuring the correlation of each dimension with the questionnaire as a whole. All of these were linked at the level of significance of 0.01 , indicating that the questionnaire has a very high degree of honesty.

Table 2. Pearson correlation coefficient between axis and total score

\begin{tabular}{lcc}
\hline Dimension & Number of paragraphs & Pearson coefficient \\
\hline Axis I: Factors leading to job stability & 6 & $.471^{* *}$ \\
\hline $\begin{array}{l}\text { The second axis: the impact on the overall } \\
\text { productivity of the organization }\end{array}$ & 6 & $.831^{* *}$ \\
$\begin{array}{l}\text { The third axis: the impact on the quality of } \\
\text { the plant's productivity }\end{array}$ & 6 & $.879^{* *}$ \\
\hline
\end{tabular}

Source: Field study procedures 2018.

Stability of the questionnaire: Determination of the stability of the questionnaire was determined by the Alpha Kornbach coefficient. The value of Alpha Kornbach ranged from 0.530 to 0.661. The value of the Alpha Kronbach coefficient was 0.752 , indicating that the questionnaire had a good degree of stability. 
Table 3. Alpha Kronbach coefficient

\begin{tabular}{lcc}
\hline Dimension & Number of paragraphs & Vaccronbach coefficient \\
\hline Axis I: Factors leading to job stability & 6 & 0.530 \\
\hline $\begin{array}{l}\text { The second axis: the impact on the overall } \\
\text { productivity of the organization }\end{array}$ & 6 & 0.661 \\
\hline $\begin{array}{l}\text { The third axis: the impact on the quality of } \\
\text { the plant's productivity }\end{array}$ & 6 & 0.637 \\
\hline \begin{tabular}{l} 
The questionnaire as a whole \\
\hline
\end{tabular} & 18 & 0.752 \\
\hline
\end{tabular}

Source: Field study procedures 2018.

\subsection{Data Collection Procedures}

After the design of the survey questionnaire, 135 questionnaires were distributed to the research community. After the screening and verification, 82 questionnaires were valid for analysis. After receiving the forms, the SPSS program was processed.

Statistical methods used:

- Pearson correlation coefficient.

- Alpha Kornbach Laboratories.

- Duplicates and percentages.

- Arithmetic mean and standard deviation.

- Simple linear regression.

4.3 Results of the Questionnaire Analysis

First: The personal data of the sample members:

1. Age

Table 4. Age

\begin{tabular}{lll}
\hline Age & Repetition & Ratio \\
\hline Less than 30 years & 46 & $56 \%$ \\
\hline $30-40$ years & 28 & $34 \%$ \\
\hline 40 years and above & 8 & $10 \%$ \\
\hline Total & 82 & $100 \%$ \\
\hline
\end{tabular}

Source: Field study procedures 2018.

From the data in the table above, it is clear that the age group (less than 30 years) came in at $56 \%$, followed by the age group (30-40 years) by 34\%, and the last age group (40 years and over) Indicates that the majority of the sample is young.

2. Sex

Table 5. Sex

\begin{tabular}{lcc}
\hline Sex & Repetition & Ratio \\
\hline Male & 82 & $100 \%$ \\
\hline Female & 0 & $0 \%$ \\
\hline Total & 82 & $100 \%$ \\
\hline
\end{tabular}

Source: Field study procedures 2018. 
From the table data above it is clear to us that all members of the research sample are $100 \%$ male.

3. Scientific qualification

Table 6. Scientific qualification

\begin{tabular}{lll}
\hline Qualification & Repetition & Ratio \\
\hline BA & 54 & $66 \%$ \\
\hline Secondary & 22 & $27 \%$ \\
\hline Less than secondary & 6 & $7 \%$ \\
\hline Total & 82 & $100 \%$ \\
\hline
\end{tabular}

Source: Field study procedures 2018 .

Of the above table data, it is clear to us that those with a bachelor's degree came $66 \%$, secondary by $27 \%$ and less than secondary by $7 \%$.

4. Do you work full-time or part-time?

Table 7. Do you work full or part time?

\begin{tabular}{lcc}
\hline Age & Repetition & Ratio \\
\hline Full & 17 & $21 \%$ \\
\hline Partial & 65 & $79 \%$ \\
\hline Total & 82 & $100 \%$ \\
\hline
\end{tabular}

Source: Field study procedures 2018.

Of the above table data it is clear that part-time workers are $79 \%$ and full-time employed at $21 \%$. This indicates that the majority of employees work part-time.

5. How are your business hours?

Table 8. Working hours

\begin{tabular}{lcc}
\hline Age & Repetition & Ratio \\
\hline During the day & 60 & $73 \%$ \\
\hline During the night & 14 & $17 \%$ \\
\hline Night / Day alternate & 8 & $10 \%$ \\
\hline Total & 82 & $100 \%$ \\
\hline
\end{tabular}

Source: Field study procedures 2018.

Of the above table data, it is clear that only $73 \%$ worked during the day, $17 \%$ worked during the night, and $10 \%$ worked day and night. This indicates that most of the factory activity is daytime.

\subsection{Second: The Study Hypotheses}

\subsubsection{Results of the First Hypothesis}

The first assumption states that "there is a relationship between factors leading to job stability and employee performance." 
Table 9. Mathematical averages and standard deviations of the factors of job stability

\begin{tabular}{clcccc}
\hline No. & \multicolumn{1}{c}{ Phrase } & SMA & $\begin{array}{c}\text { standard } \\
\text { deviation }\end{array}$ & Overall ratio & $\begin{array}{c}\text { Degree of } \\
\text { approval }\end{array}$ \\
\hline 1 & $\begin{array}{l}\text { I always think about changing my } \\
\text { work }\end{array}$ & 3.16 & 1.143 & $63 \%$ & neutral \\
\hline 2 & $\begin{array}{l}\text { My work makes me reassured and } \\
\text { satisfied with my professional } \\
\text { future }\end{array}$ & 3.52 & 1.159 & $70 \%$ & Agree \\
\hline $3 \quad \begin{array}{l}\text { There is equality and equality in } \\
\text { the treatment of workers }\end{array}$ & 3.20 & 1.190 & $64 \%$ & neutral \\
\hline 4 & $\begin{array}{l}\text { Paid wages are commensurate } \\
\text { with the prevailing level in the } \\
\text { market }\end{array}$ & 3.00 & 1.118 & $60 \%$ & neutral \\
\hline 5 & $\begin{array}{l}\text { The incentives are determined on } \\
\text { the basis of accuracy and } \\
\text { objectivity }\end{array}$ & 2.80 & 1.155 & $56 \%$ & neutral \\
\hline 6 & $\begin{array}{l}\text { I feel that there is a benefit from } \\
\text { my competence in my workplace }\end{array}$ & 3.08 & 1.187 & $62 \%$ & neutral \\
\hline$\quad$ Total & 3.13 & 0.633 & $63 \%$ & neutral \\
\hline
\end{tabular}

Source: Field study procedures 2018.

From the above table data, it is clear that the percentage of the total concentration of factors leading to job stability and employee performance was $63 \%$, which indicates a relationship between job stability and performance level to a medium degree. And there is justice and equality in the treatment of workers by $64 \%$, and to verify the validity of the hypothesis was conducted regression test results came:

Table 10. Simple linear regression between the factors of job stability and employee performance level

\begin{tabular}{cccccccccc}
\hline \multirow{2}{*}{ Model } & \multicolumn{2}{c}{$\begin{array}{c}\text { Unstandardized } \\
\text { Coefficients }\end{array}$} & Beta & T & Sig. & R & R Square & F & Sig. \\
\cline { 2 - 7 } & B & Std. Error & & & & & & & \\
\hline $1($ Constant) & 2.209 & 1.144 & & 1.930 & .066 & $.160^{\mathrm{a}}$ & .026 & .606 & $.044^{\mathrm{b}}$ \\
$\mathrm{X} 1$ & 0.278 & .357 & .160 & .779 & .044 & .046 \\
\hline
\end{tabular}

Source: Field study procedures 2018.

From the data of the previous table we find that the value of " $\mathrm{t}$ " was significant, indicating that the independent variable has a mean effect on the dependent variable, and the value of " $\mathrm{f}$ " is significant, indicating that the model is significant, and we find that the value of Pearson "R" (0.160). The coefficient of determination (R2) was 0.026 , indicating that the independent variable could interpret $2.6 \%$ of the changes associated with the dependent variable only. It is clear from these results that:

There is a statistically significant relationship between job stability and employee performance.

$\mathrm{Y}=2.209+0.278 \mathrm{X} \_1$ Thus, the regression equation can be written as follows:

Where (Y) employee performance rate, (X1) job stability. 


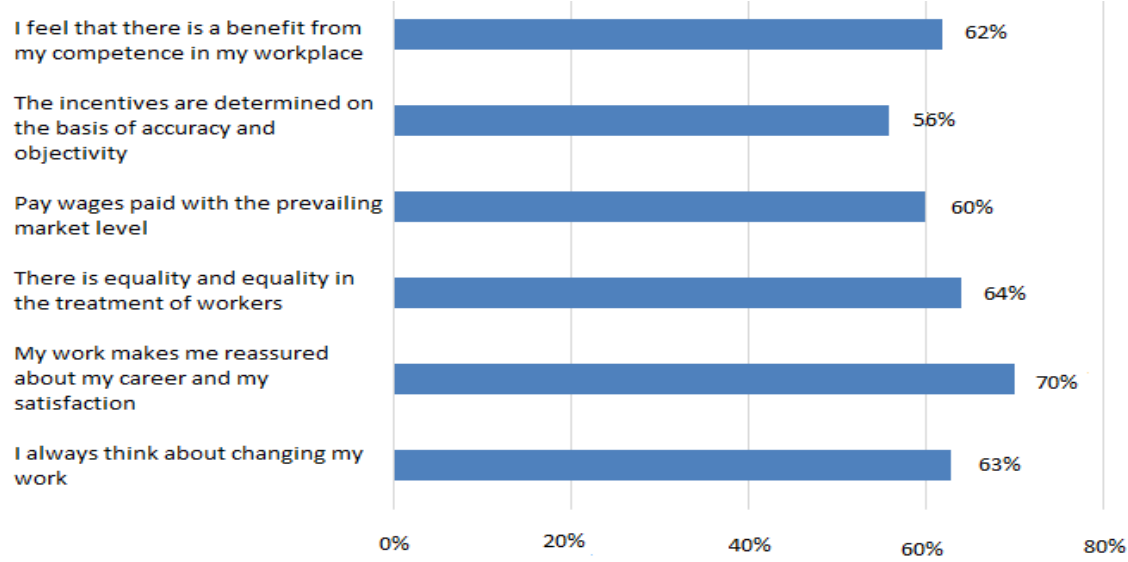

Figure 1. Stability factors

\subsubsection{Results of the Second Hypothesis}

The second hypothesis states that "there is a statistically significant relationship between the level of employee performance and the total productivity level of the organization."

Table 11. Calculation averages and standard deviations of the total productivity level in the organization

\begin{tabular}{clcccc}
\hline No. & \multicolumn{1}{c}{ Phrase } & SMA & $\begin{array}{c}\text { Standard } \\
\text { deviation }\end{array}$ & $\begin{array}{c}\text { Overall } \\
\text { ratio }\end{array}$ & $\begin{array}{c}\text { Degree of } \\
\text { approval }\end{array}$ \\
\hline $1 \quad \begin{array}{l}\text { The management measures the rate of } \\
\text { implementation of the goals set out in the production } \\
\text { plan periodically }\end{array}$ & 3.40 & 1.414 & $68 \%$ & Agree \\
\hline 2 & $\begin{array}{l}\text { The Administration takes corrective action when a } \\
\text { performance deviation is observed }\end{array}$ & 3.20 & 1.472 & $64 \%$ & Neutral \\
\hline 3 & Manufactured materials are regularly marketed & 3.40 & 1.443 & $68 \%$ & Agree \\
\hline 4 & $\begin{array}{l}\text { Some items are returned due to technical defects due } \\
\text { to loading and unloading }\end{array}$ & 2.96 & 1.306 & $59 \%$ & Neutral \\
\hline 5 & $\begin{array}{l}\text { Do you see incentives as essential for success and } \\
\text { quality of productivity? }\end{array}$ & 3.52 & 1.418 & $70 \%$ & Agree \\
\hline 6 & $\begin{array}{l}\text { The factory suffers from competition for foreign } \\
\text { goods }\end{array}$ & 3.52 & 1.388 & $70 \%$ & Agree \\
\hline$\quad$ Total & 3.33 & 0.858 & $67 \%$ & Neutral \\
\hline
\end{tabular}

Source: Field study procedures 2018.

The table above shows that the total of the axis was $67 \%$, which is an average ratio indicating that there is a statistically significant relationship between the employee performance level and the total productivity level in the organization. The production plan is periodically measured at $68 \%$, and the management measures the percentage of implementation of the goals set out in the production plan periodically by $68 \%$, while $70 \%$ of the sample of the research that the factory suffers from competition of foreign goods. To verify the validity of the hypothesis, the linear regression analysis was performed. The results were as follows: 
Table 12. The simple linear regression between the level of employee performance and the overall productivity level of the organization

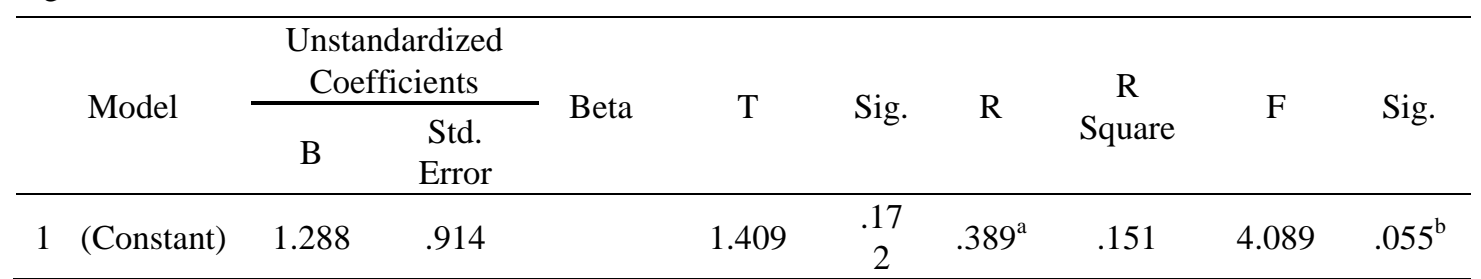

Source: Field study procedures 2018.

From the data of the previous table we find that the value of " $\mathrm{t}$ " was significant, indicating that the independent variable has a positive effect on the dependent variable, and the value of "f" was significant, indicating that the model is significant, and we find that the value of Pearson "R" (0.389). The coefficient of determination (R2) was 0.151, indicating that the independent variable was able to interpret $15.1 \%$ of the changes associated with the dependent variable. It is clear from these results that:

There is a relationship of statistical significance between the average level of employee performance and the overall productivity level of the organization

Thus, the regression equation can be written as follows: $\mathrm{Ys}=1.288+0.538 \mathrm{X} \_2$

Where (Ys) and the total productivity level of the organization, (X2) the level of performance of the employee.

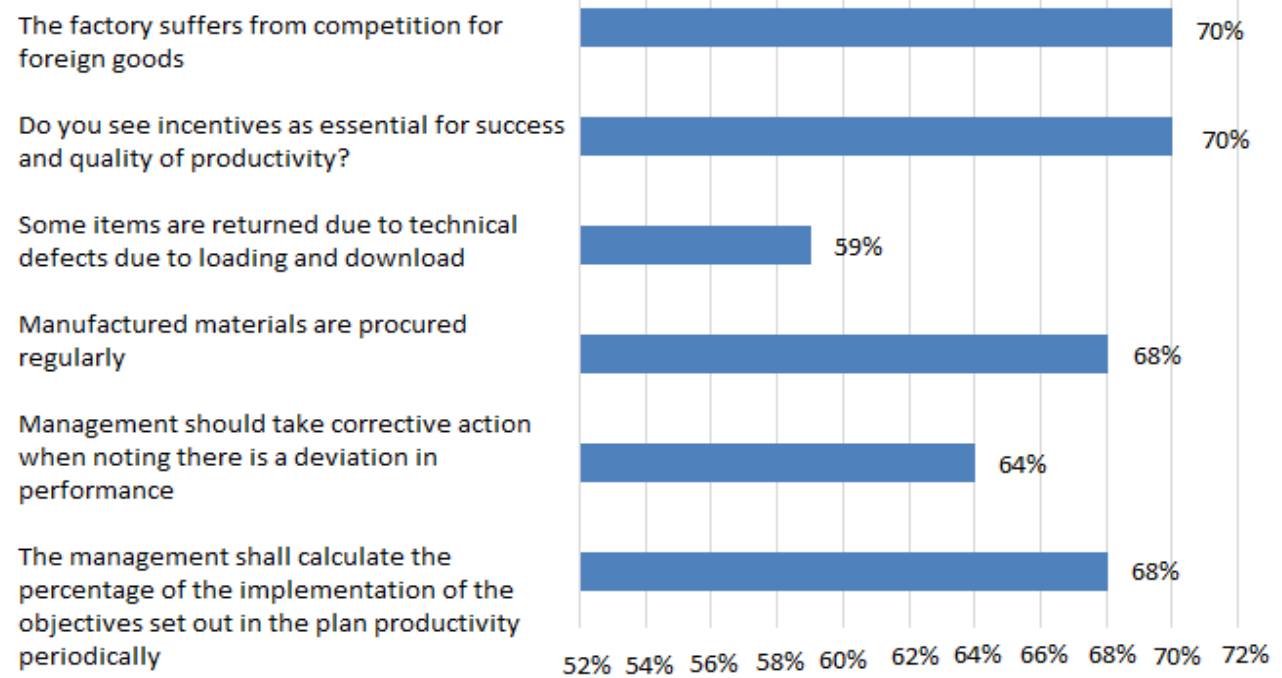

Figure 2. The level of productivity of the institution

\subsubsection{Results of the Third Hypothesis}

The third hypothesis states that "there is a relationship between the turnover rate and the quality of productivity in the industrial sector."

Table 13. Calculation averages and standard deviations of the level of productivity quality

\begin{tabular}{llccccc}
\hline No. & Phrase & SMA & $\begin{array}{c}\text { Standard } \\
\text { deviation }\end{array}$ & $\begin{array}{l}\text { Overall } \\
\text { ratio }\end{array}$ & $\begin{array}{l}\text { Degree of } \\
\text { approval }\end{array}$ \\
\hline 1 & $\begin{array}{l}\text { The communication system between me and my } \\
\text { superiors is weak }\end{array}$ & 2.88 & 1.301 & $58 \%$ & Neutral \\
\hline
\end{tabular}




\begin{tabular}{llllll}
\hline 2 & $\begin{array}{l}\text { I communicate with my colleagues and work with } \\
\text { them in team spirit }\end{array}$ & 3.32 & 1.435 & $66 \%$ & Agree \\
\hline 3 & $\begin{array}{l}\text { There is a healthy working environment and adequate } \\
\text { safety means }\end{array}$ & 3.20 & 1.258 & $64 \%$ & Neutral \\
\hline 4 & Availability of modern technology in the factory & 3.08 & 1.579 & $62 \%$ & Neutral \\
\hline 5 & Transportation is not available at all times & 3.12 & 1.509 & $62 \%$ & Neutral \\
\hline 6 & $\begin{array}{l}\text { Health and family reasons hamper my continued } \\
\text { work }\end{array}$ & 2.76 & 1.332 & $55 \%$ & Neutral \\
\hline & 3.06 & 0.839 & $61 \%$ & Neutral \\
\hline
\end{tabular}

Source: Field study procedures 2018.

Of the data in the table above shows that the total percentage of the quality level of the productivity level was $61 \%$, which means that the quality of productivity was low, although "working with colleagues and working with them in team spirit" is $66 \%$ A healthy working environment and adequate safety means of $64 \%$, and modern technology is available in the factory by $62 \%$, and to ensure the validity of the hypothesis was conducted a simple linear regression test results were as follows:

Table 14. The simple linear regression between the turnover rate and the surrounding conditions

\begin{tabular}{cccccccccc}
\hline \multirow{2}{*}{ Model } & \multicolumn{2}{c}{$\begin{array}{c}\text { Unstandardized } \\
\text { Coefficients }\end{array}$} & Beta & T & Sig. & R & R Square & F & Sig. \\
\cline { 2 - 7 } & B & Std. Error & & & & & & & \\
\hline 1(Constant) & 3.979 & .922 & & 4.314 & .000 & $.179^{\mathrm{a}}$ & .032 & .766 & $.041^{\mathrm{b}}$ \\
X3 & 0.255 & .291 & .179 & .875 & .051 & \\
\hline
\end{tabular}

Source: Field study procedures 2018.

The value of " $\mathrm{t}$ " is significant, indicating that the independent variable has a positive effect on the dependent variable, and the value of " $\mathrm{f}$ " is significant, indicating that the model is significant, and we find that the value of Pearson " $\mathrm{R}$ " (0.179), and the coefficient of determination (R2) was (0.032). This indicates that the independent variable was able to interpret $3.2 \%$ of the changes associated with the dependent variable. It is clear from these results that:

There is a negative relationship between the turnover rate and the level of productivity at the plant.

Thus, the regression equation can be written as follows: $Y f=3.979+0.255 X \_3$

Where (Ys) productivity level, (X3) turnover rate.

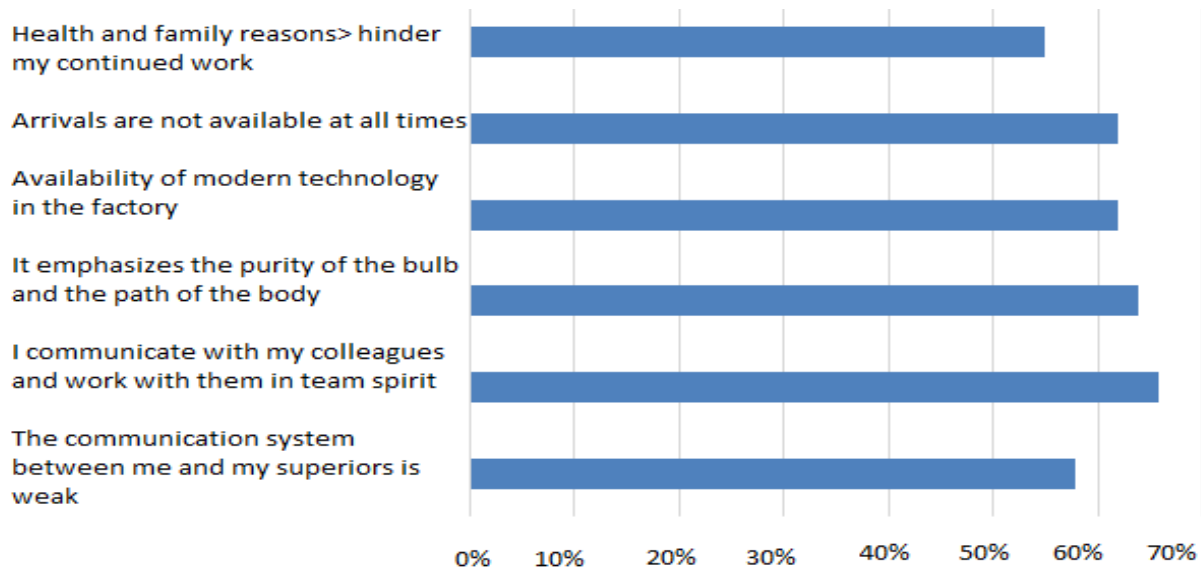

Figure 3. Quality level of productivity in the factory 


\section{Results}

1. The majority of the sample is young because the age group (less than 30 years) came in the lead with 56\%, followed by the age group (30-40 years) by $34 \%$, and the last age group (40 years and above) .

2. All male respondents are $100 \%$ male.

3. The majority of the sample has a university qualification, with a bachelor's degree of $66 \%$, secondary by $27 \%$ and less than secondary by $7 \%$.

4. Most of those who work in the factory work part-time at $79 \%$, while full-time work at $21 \%$.

5. The activity of the factory is most daytime, with only $73 \%$ working during the day, $17 \%$ working nighttime, and $10 \%$ night shift.

6. That the percentage of the total concentration of the stability of the job and the level of performance provided by the employee came at $63 \%$, indicating that there is a relationship of statistical significance between the average stability of the employee performance level.

$\mathrm{Y}=2.209+0.278 \mathrm{X} \_1$ Thus, the regression equation can be written as follows:

Where (Y) employee performance rate, (X1) job stability

7. That the total number of the axis was $67 \%$, which is an average ratio indicating that there is a relationship of statistical significance between the average level of employee performance and the level of productivity in the organization

Thus, the regression equation can be written as follows: $\mathrm{Ys}=1.288+0.538 \mathrm{X} \_2$

8. That the total percentage of the axis of working conditions was $61 \%$, which means that there is a negative relationship between the turnover rate and the quality of productivity in the factory.

Thus, the regression equation can be written as follows: $\mathrm{Yf}=3.979+0.255 \mathrm{X} \_3$

Where (Ys) productivity level, (X3) turnover rate.

\section{Conclusion and Future Work}

There are several factors influencing the process of work turnover: emotional stress associated with psychological and moral aspects, the level of support the organization to workers to do their work, institutional justice among workers, job satisfaction and the extent of organizational loyalty, the nature of work and physical and moral conditions, effective leadership and the ability to influence the subordinates During effective communication. Therefore we recommend the following:

1. The need for institutions to raise the rate of wages commensurate with the living conditions and needs.

2. We recommend the decision makers to work to determine the minimum wage paid by workers in the industrial sector, especially the industrial cities and applied strictly and reduce the manipulation of employers with the wages of workers.

3. Employers should provide appropriate incentives to existing workers to reduce the turnover of work in institutions, because turnover is a cost borne by institutions and can be eliminated by retaining staff.

4. Working to comply with the number of working hours and if there is a need for longer working hours, the employees are rewarded well.

5. Provide health insurance and all means of reducing the work difficulties faced by workers.

6. Develop staff relations among themselves and develop their relationships with departments, which is considered one of the most important standards of quality work.

7. Updating and developing the work environment through the development of complete systems of total quality of tools, means, programs and equipment that facilitate the work of employees, and provide them with all possibilities to work in a high quality manner.

8. Work hard to improve the level of job stability by increasing end of service benefits, providing a social security fund, providing future security in the event of retirement, and drafting official documents and clear decisions that show each employee his rights and how to obtain them and how to maintain them.

9. Promote, develop and improve the relationship between management and employees so as to be a good lever to contribute to the development of the individual and the institution and their integration through respect and 
appreciation and fruitful cooperation in order to provide the best services, through the work of the team spirit of cooperation, and through the clear administrative instructions and realism arising from the need for work.

10. Emphasize the dissemination of the culture of total quality among employees through public meetings, and the need to assess their efforts and give them through the coordination of clear and permanent, and all these factors will contribute to strengthen the loyalty of employees and their belonging to their work and adherence to their jobs and prevents their infiltration of other jobs.

11. Develop the level of desire and readiness of the employees to carry out any task for the purpose of survival and continuity of work and the consolidation of the values of the Union and published and clarified to the workers well.

12. Establish clear and stated rules and controls to ensure the quality of employee performance and thus the quality of productivity, and encourage them to acquire and develop various skills and abilities according to the principles of total quality and provide opportunities to acquire new skills that meet the requirements of work.

\section{References}

Abbas Mahmoud Awad. (1977). Studies in Industrial Psychology. The General Egyptian Book Organization, Alexandria, p. 54.

Abdel-Aal, Adel El Sayed. (2014). Effect of Employee Satisfaction on Employment Turnover - Applied Study on Al-Babtain Company for Energy and Telecoms. Research Proposal for a Professional Doctorate Degree in Business Administration, Egypt.

Abdul Wahab Ahmed Abdul Wasa. (1973). Department of Personnel Management, Riyadh, p. 81.

Ahmed Zaher Al-Enezi. The Role of Public Sector in the State of Kuwait, pp. 38-40, Retrieved from gulfpoliciees.com

Al-Humaidi M. Al-Mutairi. The Effect of Employee Turnover on Financial Performance, pp. 10-11. Retrieved from researchgate.not

Bandar bin Fahad Mohammed Al-Harbi. National Employment Leakage from the Private Sector: Reasons and Proposed Solutions, p. 17. Retrieved from faculty.ksa.edu.sa

Majid Fahd Saud Al-Qurashi. Work pressure and its impact on the work turnover of the employees of the Border Guard Centers in the Eastern Province, pp. 57-58. Retrieved from nauss.edu.sa

Malik Mohammed bin Makki Al-Sawaf. Functional Leakage Definition, Types and Results, pp. 32-33. Retrieved from faculty.ksa.edu.sa

Mohammed Maher Alish. Principles of Human Resources Management, Publications Agency, Fahad Al-Kawth Street, p. 34.

Naim Rifai. (1969). Psychological workmanship study in the psychology of the profession. Damascus, p. 493.

\section{Notes}

Note 1. Alish, Mohammad Maher (1985) Human Resources Department, Publications Agency, Kuwait, p.

Note 2. Al-Mutairi, Al-Humaidi Mohammed (2012) Effect of Employee Turnover on Financial Performance Applied Study in the Kuwaiti Islamic Banking Sector, Master Thesis Presented at Middle East University, Jordan.

Note 3. Abdel-Aal, Adel El Sayed (2104), Effect of Employee Satisfaction on Employment Turnover - Applied Study on Al-Babtain Company for Energy and Telecoms, Research Proposal for a Professional Doctorate Degree in Business Administration, Egypt.

Note 4. Al-Humaidi M. Al-Mutairi, The Effect of Employee Turnover on Financial Performance, pp. 10-11, researchgate.not

Note 5. Previous reference

Note 6. Ahmed Zaher Al-Enezi, The Role of Public Sector in the State of Kuwait, pp. 38-39-40, gulfpoliciees.com

Note 7. Majid Fahd Saud Al-Qurashi, Work pressure and its impact on the work turnover of the employees of the Border Guard Centers in the Eastern Province, pp. 57-58, nauss.edu.a 